\title{
Intersections
}

Canadian Journal of Music

Revue canadienne de musique

\section{Katherine Ellis. 2005. Interpreting the Musical Past: Early Music in Nineteenth-Century France. Oxford and New York: Oxford University Press. Personalia, bibliography, and index, xxii, 295 pp. ISBN 0-19-517682-0 (hardcover)}

\section{Catrina Flint de Médicis}

Volume 26, numéro 1, 2005

URI : https://id.erudit.org/iderudit/1013250ar

DOI : https://doi.org/10.7202/1013250ar

Aller au sommaire du numéro

Éditeur(s)

Canadian University Music Society / Société de musique des universités canadiennes

ISSN

1911-0146 (imprimé)

1918-512X (numérique)

Découvrir la revue

Citer ce compte rendu

Flint de Médicis, C. (2005). Compte rendu de [Katherine Ellis. 2005. Interpreting the Musical Past: Early Music in Nineteenth-Century France. Oxford and New York: Oxford University Press. Personalia, bibliography, and index, xxii, 295 pp. ISBN 0-19-517682-0 (hardcover)]. Intersections, 26(1), 160-165.

https://doi.org/10.7202/1013250ar

Copyright @ Canadian University Music Society / Société de musique des universités canadiennes, 2006
Ce document est protégé par la loi sur le droit d'auteur. L'utilisation des services d'Érudit (y compris la reproduction) est assujettie à sa politique d'utilisation que vous pouvez consulter en ligne.

https://apropos.erudit.org/fr/usagers/politique-dutilisation/ 
was universal; I ask Patu what it means, and he answers seriously that the applause was for Duprés grace and the divine harmony of his movements. He was, he said, sixty years of age [an exaggeration], and he was the same as he had been forty years earlier. (Casanova 1968, 2 [3], 142)

I am convinced that Rameau must have fashioned his lengthy chaconne (and its hysterically funny effect on poor Platée) with Dupré in mind (he had also performed in the Versailles premiere).

In every respect this new edition of Platée is first rate. It captures so much information that it takes a good deal of time and patience (more, certainly, than the title character would ever put up with or endure) to digest it all. It fashions a score (or scores) and critical apparatus in which I have yet to spot a single slipup. It is meticulous in its documentation. And yet I sense, as I am sure many others will, a huge reservoir of knowledge backing the edition up, supporting it without specific reference. That, too, is part of Beth Bartlet's legacy.

\section{REFERENCES}

Casanova, Giacomo. 1968. History of my Life, trans. by Willard R. Trask, 12 vols. in 6. New York: Harcourt, Brace and World. 2 [3], 142.

Mercure de France (March 1754):180-181.

Rameau, Jean-Philippe. 1990. Platée. Ensemble Vocale Françoise Herr, Les Musiciens du Louvre, Marc Minkowski, director. Radio France/EratoDisques 2292-45028-2. Compact disc.

Rameau, Jean-Philippe. 1988. Platée. La Grande Écurie et La Chambre du Roy, Jean-Claude Malgoire, director. CBS Records M2K 44982. Compact disc.

Recueil de Contredanses avec la Basse Chiffrée; et la Table par Lettres Alphabétiques. Qui se dansent au bal de l'Opéra, et de St Cloud. n.d. Paris.

Rosow, Lois. 2005. "Rameau's galante orgy." Early Music 33:714-716.

Semmens, Richard. 1997. "Branles, Gavottes and Contredanses in the Later Seventeenth and Early Eighteenth Centuries." Dance Research 15/2:46.

Semmens, Richard. 2004. The bals publics at the Paris Opera in the Eighteenth Century. New York: Pendragon.

Williams, Jonathan Huw, ed. 2004. Jean-Philippe Rameau, Anacréon: ballet héroiqque en un acte. Kassel: Bärenreiter.

RICHARD SEMmENS

Katherine Ellis. 2005. Interpreting the Musical Past: Early Music in NineteenthCentury France. Oxford and New York: Oxford University Press. Personalia, bibliography, and index. xxii, 295 pp. ISBN 0-19-517682-0 (hardcover).

Few scholars other than Katharine Ellis could have written Interpreting the Musical Past: Early Music in Nineteenth-Century France. For this monograph draws extensively on the author's substantial experience with French music criticism, as well as her sophisticated understanding of that nation's political 
and cultural history. There is also very clearly an active musician behind the pen here, one sensitive to issues of musical style and performance practices. Interpreting the Musical Past is a mature work that reveals a wealth of knowledge through a highly variegated but always compelling and persuasive literary style. It is an exemplary model for scholars in general of what musicology can be.

Beginning with three introductory chapters that provide a survey of the early music revival in nineteenth-century France, Ellis continues with four detailed case studies of individual repertoires: French Baroque music (Chapter 4); French Medieval and Renaissance works (Chapter 5); Palestrina (Chapter 6); and Baroque choral pieces (Chapter 7). While some might question the structure of the book, Ellis's choice to avoid a completely chronological progression makes absolute sense. Each of the repertoires explored in Chapters 4 through 7 comes with its own very complicated cultural baggage, which would have created huge asides in a chronologically-driven narrative.

Ellis's tremendous grasp of nineteenth-century French politics and identity is clear throughout the book, and one excellent example is her chapter on Baroque choral music. Here readers learn how the German composer Georg Friedrich Händel was appropriated in the late 1860 s and early 1870 s by French choral societies and reinterpreted by critics and writers as a Latinized composer. This chapter is also a forceful lesson in the connection between gender and national identity politics in nineteenth-century France: Ellis tells readers that the Latinized Handel rose to popularity mainly as a musical emblem of masculinity and military might. This was partly the result of translations that imbued Handel's oratorio texts with a greater sense of virility, and partly because of the diatonic and homophonic style of his music (p. 217). The latter is extremely important: as Ellis shows in some detail, there was a concerted effort by Louis BourgaultDucoudray and others to bring Handel to the masses in the 1870s, through performances by male worker choirs or orphéons (pp. 222-31). The more complex textures of some of Bach's choral music, and the chromatic language of his harmony were not suited to this type of goal at the time.

Even though it might be tempting to attribute the appropriation of a hypermasculine, warlike Handel during the 1870 s to a search for models of the potent French male following the nation's emasculating defeat in 1871, Ellis only concedes this in part. By looking to Handel biographies of the 1860 s, she is able to show that the idea of Handel as a warrior was not a direct effect of the Franco-Prussian war. This last point demonstrates Ellis's forward thinking. The year of 1871 is often thrown up as a high boundary wall between what are often characterized as "frivolous" musical trends of the Second Empire and an impulse to create more "serious" works that began with the Third Republic. But here and elsewhere in the book, Ellis has blurred that boundary, revealing it for the somewhat artificial chronological marker that it is, and contributing to an emerging impulse within the field (see for example Mordey 2007).

That being said, Ellis does stress the importance of the humiliation of 1871 in her fourth chapter on the performance and publication of French Baroque comic operas or la musique française, as it was referred to during the period. But she reminds readers that the vocabulary used to describe Frenchness after 
1871 (i.e., concision, nobility, grandeur, charm, naivety) actually originated in the 1850s (p. 142). She also helps to break down another common assumption: that defeat at the hands of the Germans engendered a knee-jerk championing of all things French. In this Ellis is following in the footsteps of scholars such as Michael Strasser, who has convincingly argued that the newly-formed Sociéte nationale de musique's motto ars gallica was not formulated as an adversarial battle cry against foreign works as one might expect in the wake of 1871 (Strasser 2001). Ellis's contribution to our understanding of French national identity and musical values during this time is her underscoring of the fact that la musique française was gendered female as a result of its associations with dance, and because it also had "popular" appeal. Like her observations on the masculinizing of Handel, this is an important contribution to the history of ideas, and especially to the notion that mass or popular culture became increasingly feminized during the nineteenth century (Huyssen 1986, 44-62). Indeed, she points out that one of the greatest impediments to the revival of Rameau's dramatic works during the 1890 s and early 1900 s was a prior history of performing "feminine" dance works by this same composer.

There is another important strand that weaves through Ellis's chapter on la musique française, and that is her insistence on the gulf between early music that was published by Théodore Michaëlis in the 1870s and 1880s in the Chefsd'euvre classiques de l'Opéra français (a multi-volume subscription edition of early French operas), and pre-1750 music that was performed during the same time period (p. 138). This is also an issue that she addresses in her fifth chapter called "Sources of Frenchness." This chapter is essentially given over to Renaissance and Medieval music. She explains how French musicians from the time of Fétis interpreted history in order to claim Flemish composers such as Josquin and Lassus for France (pp. 147-52), and highlights the great discrepancy between this desire to appropriate these Renaissance composers and an almost complete rejection of the sacred music they wrote. What appealed to the French, from Fétis to de la Fage and Weckerlin, was a small corpus of Franco-Flemish chansons, which acquired essentially "nationalist" associations and were also masculinized (pp. 156-64). Ellis also looks at performances and editions of Adam de la Halle's Le Jeu de Robin et de Marion (pp. 164-70), a work that Fétis described as "the oldest opéra-comique in existence." (p. 165) Her treatment of this work is in no way gratuitous: the piece was appropriated as the foundation for the history of French music by Alfred Bruneau in 1900, whose "report" on French music for the World's Fair was hotly debated (Bruneau 1901).

Ellis's book includes a very thick chapter on the Palestrina revival in France, which began in the 1820s and 30s with the work of Alexandre Choron, continued in the 1840s with the Prince de la Moskowa and Adrien de la Fage, and survived in the ensuing decades through the efforts of Joseph Régnier and Louis Niedermeyer, Charles Vervoitte, and Gustave Lefevre. Understanding the history behind the well-known performances of sacred music by Palestrina given at the Église Saint-Gervais by Charles Bordes in the 1890s makes those events seem far less seminal in nature and much more of a final hurrah for a repertoire that effectively disappeared for over a decade after 1900 . While this chapter 
is unquestionably a demanding read, it highlights key issues in the reception of Palestrina's music that stemmed from debates over sacred music. These debates were further complicated by the division of the church in France between Ultramontane and Gallican Catholics: one ceded absolute authority to the pope in Rome, the other claimed exceptional privileges and differences of rite for itself. To have treated the performance of Palestrina's music in nineteenth-century France outside the context of these debates would have been something of a travesty. Ellis shows how radical Ultramontane Catholics preferred chant to polyphony for use in the church, including the music of Palestrina, which they described as non-communal. As we saw in the chapters on la musique française and choral music, musical style had ideological associations: in this case, counterpoint could never be radically Ultramontane (pp. 181-82). Yet "works with the allure of harmonized chant" by this same composer were promoted as ideal sacred music by moderate Ultramontanes (p. 182).

The idea of the essentially French is never far from the surface in this chapter. Indeed, Ellis returns to an idea that she explored in her fourth chapter, and this is French musical self-hatred. For her the appeal of Palestrinian musiceven with Gallicans-rested on this tremendous devaluation for the musically French, combined with stylistic interpretations of his music: a "harmonic" Palestrina educated by the French composer Goudimel made a good replacement for the sacred motets of Lalande and Rameau. Likewise, performance practices are carefully intertwined in the argument: massed choirs performing works in slow tempi with piano dynamics and staggered breathing stripped the music of Palestrina from any associations with "dramatic" composers such as Monteverdi and the "individuality" of Renaissance artists that ran counter to Ultramontane communitarian ideals (pp. 188-91). In Ellis's words: "the question of 'dramatic passion' (with its implications of humanist individualism) or its absence (with concomitant implications of Medieval collectivism) lay accordingly at the heart of Palestrina's reception throughout the century." (p. 189)

If anti-Palestrina sentiment intensified alongside anti-Clericalism at the end of the nineteenth century (p. 199), the rejection of Palestrina's music was also deeply-seated in longstanding perceptions of his religious works by sacred music thinkers as either "inherently unpopular" (p. 198); disturbingly "pure and sensual alike" (p. 199); or as creating "mystery and thus deceit" (p. 201). During the 1890s, Palestrina was reinterpreted by individuals associated with Bordes and the Schola Cantorum as the final composer of the Middle Ages so that he could be freed of any associations with humanism and "art for art's sake" (pp. 202-05).

I have very few quarrels with this book. Ellis's exploration of "nationalism" seems simplistic at times, as it is mainly an attempt to root out essential qualities that surfaced time and again as typically "French" in writings about early music. This approaches what political theorists call "ethnic-linguistic" nationalism, or a mass movement towards homogenization that is rooted in ideal visions of race, and manifested in language. Ethnic-linguistic nationalism often carries with it negative and exclusive connotations, and Carlo Caballero has suggested that it should not be confused with the more inclusive form of national pride that is 
patriotism (Caballero 1999). But she is justified in viewing nationalism in this way: it is the model that has informed a number of scholars, including Richard Taruskin (Taruskin 2006) and Jane Fulcher (Fulcher 1999). Moreover, late nineteenth-century thinkers such as Ernest Renan did indeed conceive of the nation as a faceless collective of individuals who shared common characteristics-though he did not view this as a negative impulse (Renan 1882).

The book may have benefited from a more critical view of what scholars call the "ralliement" period: it was supposed to have been a time of coming together of moderate Republicans and Catholics during the 1890s. But the work of William Fortescue and others suggests that many Catholics opposed the ralliement (Fortescue 2000; Mayeur and Reberioux 1984; Ravitch 1990). Still, this is a short period of time in a book that covers the entire nineteenth century. Also somewhat problematic is the conflation of seventeenth and eighteenth-century French music in Ellis's fourth chapter: one was associated with the golden era of Louis XIV; the other stemmed from the reigns of monarchs whose political ineptitude led to the downfall of the monarchy. Yet while I found this conflation somewhat disturbing, I must concede that even though this distinction seems important for the early music revival during the 1890 s, it may well have been irrelevant for critical appreciations of French Baroque music in previous decades.

In the end, these objections really seem secondary. Ellis has made her points about the early music revival in France: nation matters, but so does gender; the war of 1870-71 was important, but the early music revival shows that some nationalist propensities went back further; musical style had ideological associations in nineteenth-century France; the French appear to have had little fondness for their own early music but were very adept at appropriating that of other nations (i.e., Händel's Germany and Palestrina's Italy); issues within the church were just as important for the revival of some repertoires as concerns for the nation; there was often a discrepancy between what was performed and what was published and written about; and finally, even though the nineteenth century was supposed to have been the age of "autonomous" music, it was still inexorably bound to context and questions of identity. In this last point, and in her attentive care to include early music revival efforts in the French provinces as well as the capital, Ellis has shown the way for further research on nineteenthcentury French music in general. More important, in treating a subject over the entire nineteenth century-something that is actually quite rare in the study of French music-I believe that she has revealed just how important it is for specialists not to get too bogged down in narrow time frames. Points taken. Lessons learned. Many, many thanks Professor Ellis.

\section{REFERENCES}

Bruneau, Alfred. 1901. La Musique française : rapport sur la musique en France $d u$ XIII ${ }^{e}$ au XX ${ }^{e}$ siècle. La Musique d̀ Paris en 1900 au théâtre, au concert, à l'Exposition. Paris: Bibliothèque-Charpentier. 
Caballero, Carlo. 1999. "Nationalism or Patriotism? Faure and the Great War," Journal of the American Musicological Society 52/3: 593-625

Fortescue, William. 2000. The Third Republic in France 1870-1914. London and New York: Routledge.

Fulcher, Jane. 1999. French Cultural Politics and Music: From the Dreyfus Affair to the First World War. New York and Oxford: Oxford University Press.

Huyssen, Andreas. 1986. After the Great Divide: Modernism, Mass Culture, Postmodernism. Bloomington and Indianapolis: Indiana University Press.

Mayeur, Jean-Marie and Madeleine Reberioux. 1984. The Third Republic from its Origins to the Great War, 1871-1914 translated by J. R. Foster. London and New York: Cambridge University Press.

Michaëlis, Théodore. 1877-1884. Chefs-d'œuvre classiques de l'Opéra français vols. 1-33. Paris : T. Michaëlis.

Mordey, Delphine. 2007. "Auber's Horses: The Paris Commune and apocalyptic narratives of French music history." 19th-Century Music (forthcoming).

Ravitch, Norman. 1990. The Catholic Church and the French Nation 1589-1989. London and New York: Routledge.

Renan, Ernest. 1882. "Qu'st-ce qu'une nation?" translated by Ida Mae Snyder in Nationalism edited by John Hutchinson and Anthony D. Smith, 17-18. Oxford and New York, 1994.

Strasser, Michael. 2001. "The Société Nationale and Its Adversaries: The Musical politics of 'L'invasion germanique' in the 1870s." 19th-Century Music 24/3: 225-251.

Taruskin, Richard. 2006. "Nationalism" in Grove Music Online, <www. grovemusic.com> (accessed 12 June 2006).

Catrina Flint de Médicis 